\title{
Stability of a dairy-based electrolyte replenishment beverage
}

\author{
Natali Knorr VALADÃO ${ }^{1}$, Silmara Yukari SHIMODA ${ }^{1}$, Jacqueline Costa JORY ${ }^{1}$, Guilherme Cangemi FRATASSI ${ }^{1}$, \\ Rodrigo Rodrigues PETRUS ${ }^{1^{*}}$ (D)
}

\begin{abstract}
This study targeted the commercial sterility and shelf life evaluation of an isotonic beverage formulated with ricotta cheese whey (scotta). The beverage was processed at $95^{\circ} \mathrm{C} / 50 \mathrm{~s}(\mathrm{~B} 1), 90^{\circ} \mathrm{C} / 40 \mathrm{~s}(\mathrm{~B} 2)$ and $85{ }^{\circ} \mathrm{C} / 30 \mathrm{~s}$ (B3), all stored at $25^{\circ} \mathrm{C}$ in the dark. Commercial sterility tests were carried out to evaluate the microbiological stability of the product. Hedonic scale tests were performed to estimate the beverage's shelf life. Average scores greater than 5 (in a 9-point hedonic scale) and percentage of approval greater than $60 \%$ were both used as threshold values for evaluating the overall acceptance of the product. The $\mathrm{pH}$ values, titratable acidity and soluble solids were determined at the beginning and the end of the shelf life study. The $\mathrm{pH}$ values ranged from 2.97 to 3.21 , titratable acidity from 0.358 to $0.464 \mathrm{~g}$ citric acid/100 $\mathrm{mL}$ and soluble solids from 6.35 to $6.40{ }^{\circ} \mathrm{Brix}$. All batches achieved the commercial sterility and had their shelf lives limited by the decrease of the sensory acceptability of the beverage, estimated in 100 (B1), 128 (B2) and 153 (B3) days. The milder binomial provided the longer shelf life, compatible with an eventual demand of the consumer market.
\end{abstract}

Keywords: sports drink; processing; shelf life.

Practical Application: Utilization of dairy industry residue in the production of a commercially sterilized isotonic drink.

\section{Introduction}

Ricotta cheese whey or scotta is the by-product of the ricotta production which is usually discarded or destined to animal feeding. The physicochemical characteristics presented by ricotta whey makes possible its use as an ingredient for the development of new products, being a feasible solution for reducing the environmental impact, cost reduction with treatments of dairy wastewater and, consequently, with production process. The ricotta whey is mainly composed of water, lactose and minerals. Its exploitation for an isotonic beverage formulation is a viable technological and economic alternative with great potential to add value to a by-product of the dairy industry.

According to Gironés-Vilaplana et al. (2014), the growing interest in new added-value foods and beverages with health promoting properties has led to the development of new beverages based on different kinds of waters, juices and non-alcoholic drinks enriched with fruits, as source of nutrients and bioactive compounds. Nevertheless, the consumer acceptance of these healthy products is subordinated to their quality and sensory characteristics that should be maintained during their shelf life.

The isotonic beverages have similar mineral concentrations to those found in body fluids and are formulated specifically for athletes and strenuous exercisers. Its acid $\mathrm{pH}(3.0-3.5)$ limits the microorganisms growth. Molds, yeasts, lactic and acetic acid bacteria may growth in the product (Landry et al., 2001). However, these groups are generally destroyed by the pasteurization. In this way, the combination of the high acidity, pasteurization and aseptic packaging favors the end product's preservation at ambient temperature.
The shelf life of a food product may be determined by physicochemical, enzymatic, microbiological, nutritional and sensory tests (Institute of Food Science and Technology, 1993). The sensory analysis techniques applied to a shelf life study are an essential and effective tool in monitoring the quality of food during storage. The end of shelf life may occur by the magnitude increase or decrease of the mean value of a given sensory characteristic of the product. In this context, affective sensory methods are usually carried out (Hough, 2010).

The quality and stability of the beverages are affected by oxidative reactions that depends on the process conditions, the presence of the oxygen in the headspace of the package or dissolved into the product, the gas permeation rate and barrier to the light radiation of the packaging, time and especially to the storage temperature (Graumlich et al., 1986).

Due to the dearth of published data on the shelf life of sports drinks, this study was conducted to evaluate the commercial sterility and estimated the shelf life of a ricotta whey-based isotonic drink processed in a small scale plant.

\section{Materials and methods}

The scotta-based isotonic formulation is described by Valadão et al. (2016). In that work, an isotonic drink with a good sensory acceptability was formulated. The values of osmolality, $\mathrm{pH}$ and soluble solids determined in the end product were (306 \pm 0.6$) \mathrm{mOsm} / \mathrm{kgH}_{2} \mathrm{O},(3.15 \pm 0.01)$ and $(6.4 \pm 0.0)^{\circ} \mathrm{Brix}$, respectively. The composition of $1 \mathrm{~L}$-electrolyte supplement was 
deionized water $(617.2 \mathrm{~mL})$, ricotta cheese whey $(382.8 \mathrm{~mL})$, sucrose $(36.2 \mathrm{~g})$, citric acid $(3.2 \mathrm{~g})$, tangerine flavor $(2.6 \mathrm{~mL})$ and twilight-yellow coloring $(13 \mathrm{mg})$.

\subsection{Isotonic drink processing}

The isotonic processing was performed according to Valadão et al. (2016), as followed. The scotta was obtained from the dairy plant of the University of São Paulo/Brazil, at Pirassununga/SP campus. In order to obtain the RCW, the milk whey was slowly heated to a temperature of about $85^{\circ} \mathrm{C}$. Lactic acid was then added for the whey protein denaturation to occur. The mixture was cooled to $30^{\circ} \mathrm{C}$ and the scotta separated (Maragkoudakis et al., 2016). It was then treated with lactase (EC 3.2.1.23) at a concentration of $0.1 \%\left(\mathrm{w} \mathrm{v}^{-1}\right)$ and stored at $8^{\circ} \mathrm{C}$ for $24 \mathrm{~h}$.

The isotonic beverage was pasteurized at $95^{\circ} \mathrm{C} / 50 \mathrm{~s}(\mathrm{~B} 1)$, $90{ }^{\circ} \mathrm{C} / 40 \mathrm{~s}$ (B2) and $85^{\circ} \mathrm{C} / 30 \mathrm{~s}$ (B3), cooled and aseptically filled into polyethylene terephthalate (PET) bottles. These binomials were taken from a central composite design, where the temperature ranged between 85 and $95^{\circ} \mathrm{C}$, and the holding time, between 30 and 50 s. Those treatments (B1, B2 and B3) was chosen because the product subjected to them achieved the commercial sterility. To set those ranges, the physicochemical characteristics of the sports drink, mainly its $\mathrm{pH}$ (close to 3.0), the operational capacity of the heat exchanger available for this study, as well as the thermal resistance values of molds and yeasts $\left(D_{65.6{ }^{\circ} \mathrm{C}}=0.5-1.0 \mathrm{~min}\right.$ and $\mathrm{z}=4.4$ to $5.6^{\circ} \mathrm{C}$ ) were considered (Deibel \& Jantschke, 2001). Approximately 180 units (bottles) were produced in each batch (B). Figure 1 shows the flowchart of the processing.

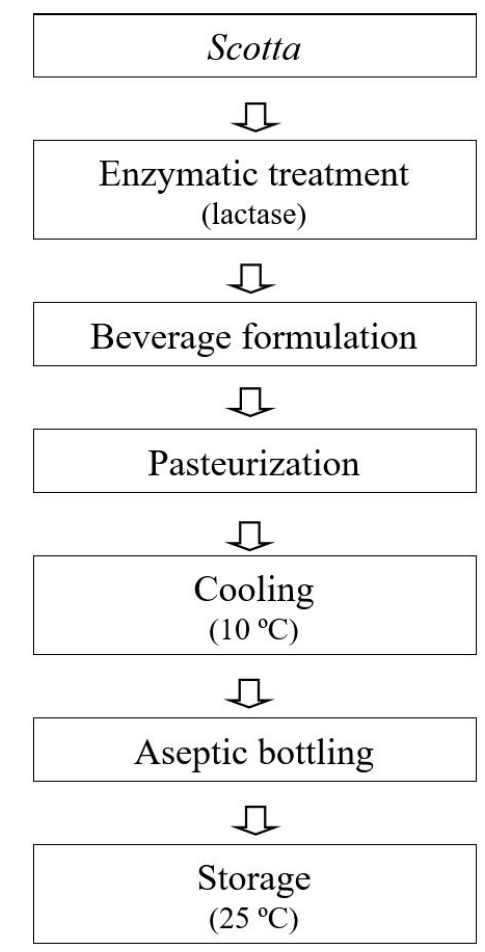

Figure 1. Flowchart of processing of scotta-based replenishment beverage.
The product was filled into $285 \mathrm{~mL}-\mathrm{PET}$ bottles decontaminated with $0.05 \%(\mathrm{v} / \mathrm{v})$ peracetic acid spray at $45^{\circ} \mathrm{C}$ for $15 \mathrm{~s}$. The bottles were hermetically sealed by induction using a sealer model Super Seal Jr., manufactured by Enercon Industries Corporation, model Super Seal Jr.

The advantages provide by the aseptic filling system include the possibility of extending the shelf life of the product and eliminating the cold chain in the transportation, distribution and storage, as well as allowing a more reliable and precise process control (Bottani et al., 2011).

After sealing, $2 / 3$ of the batch were storage at $25{ }^{\circ} \mathrm{C}$ for the commercial sterility test and shelf life study. The second fraction $(1 / 3)$ was storage at $-18{ }^{\circ} \mathrm{C}$, used as control samples in sensory tests.

\subsection{Commercial sterility test}

The commercial sterility test was conducted according to the methodology designed for high acidity food products ( $\mathrm{pH} \leq 4.6)$, described by Deibel \& Jantschke (2001). The packages were incubated at $25^{\circ} \mathrm{C}$ for 10 days and then all samples were visually examined. The $\mathrm{pH}$ values of samples from ten packages were measured. A variation of less than $0.2 \mathrm{pH}$ units in relation to the determination made immediately after processing was tolerated, according to Cerf (1988).

Five $1 \mathrm{~mL}$-samples taken from five different packages were plated in (1) Thermoacidurans Agar, incubated at $30^{\circ} \mathrm{C}$ for 5 days under aerobic and anaerobic conditions, (2) acidified Potato Dextrose Agar, incubated at $25{ }^{\circ} \mathrm{C}$ for 5 days under aerobic condition, and (3) All Purpose Tween Agar, at $30^{\circ} \mathrm{C}$ for 5 days under aerobic condition.

\subsection{Shelf life study}

The shelf life study was based on sensory and physicochemical tests, as follows.

\section{Sensory tests}

Consumer tests give a direct measure of liking, with focus on overall acceptability, that can be used more directly to estimate shelf life (Kilcast \& Subramaniam, 2000).

The sensory shelf life was determined by a panel of 100 habitual consumers (age ranging from 17 to 50 years) of isotonic beverages. The panelists were asked to evaluate the overall impression by using a 9-point hedonic scale (Meilgaard et al., 2006). The samples were individually served at a temperature of about $4{ }^{\circ} \mathrm{C}$. One drink sample, obtained from the same production batch and stored at $-18{ }^{\circ} \mathrm{C}$, naturally thawed in refrigerator 24 hours before the sensory analysis began, was taken to serve as control. Mineral water was provided to cleanse the palate. The sensory tests were monthly carried out. The average scores greater than 5 and percentage of approval equivalent or greater than $60 \%$ were used as threshold values for stablishing the product's acceptance.

The sensory evaluation sessions were initiated 15 days after the processing, considering this the time zero of the study, 
once the batches were incubated at $25^{\circ} \mathrm{C} / 10 \mathrm{~d}$, demanding five more days for completion of microbiological tests (commercial sterility test).

This study was approved by the Ethics in Research Committee from College of Animal Science and Food Engineering at University of São Paulo/SP - Brazil (Report 359.879).

\section{Physicochemical tests}

Simultaneously to the sensory analysis, physicochemical tests were conducted according to methodologies of Association of Official Analytical Chemists (Association of Official Analytical Chemists, 2012).

Soluble solids were determined using a portable digital refractometer Reichert model AR 2000, pH using pHmetrer Analyzer model $300 \mathrm{M}$ and titratable acidity using $\mathrm{NaOH} 0,1 \mathrm{M}$.

\subsection{Statistical analysis}

The data obtained from physicochemical and sensory analysis were submitted to analyses of variance (ANOVA) and Tukey test, with $95 \%$ of confidence, for means comparison. The data were processed by software SAS 9.2. Principal Components Analysis (PCA) was performed with the mean values of the investigated parameters (variables) to determine correlations between parameters and the existence of groupings between samples (Statistica program version 13, 1984-1995, Dell Inc).

Principal Components Analysis (PCA) is the statistical technique used to identify the smallest number of latent variables, called "principal components", that explain the greatest amount of observed variability in a data set (Meilgaard et al., 2006). PCA displays the relationship between samples and suggests which parameters best characterize every sample as well. Each axis, in a two-dimensional representation, explains a certain percentage of the total variability that exists between samples.

\section{Results and discussion}

\subsection{Commercial sterility test}

Visual evaluation of samples

After incubation at $25^{\circ} \mathrm{C}$ for 10 days, no defective packages were found (such as leakage or swelling); there was no evidence of spoilage. This outcome suggested that the product achieved the commercial sterility because it was stored at ambient temperature. However, this was the first step of the commercial sterility assay. Further procedures were carried out to confirm the microbiological stability, such as the measurement of the $\mathrm{pH}$ and plating in specific culture medias.

\section{Measurement of $\mathrm{pH}$}

The $\mathrm{pH}$ values are show in Table 1.

According to the $\mathrm{pH}$ values shown in Table 1, the developed drink can be considered a high-acid product. That is a powerful hurdle which favors its microbiological stability, inhibiting the growth of both spoilage and pathogen bacteria. High-acid foods are more susceptible to spoilage by yeasts and molds.

The $\mathrm{pH}$ variation $(|\Delta \mathrm{pH}|)$ was lower than 0.2 for all batches, showing the physicochemical stability of the product, according to Cerf (1988). Regarding the commercial sterility test, the measurement of $\mathrm{pH}$ is a useful supplementary information because the growth of spoilage microorganisms often renders $\mathrm{pH}$ changes.

Corso et al. (2006) evaluated the $\mathrm{pH}$ of sports drinks from different flavors and found an average of 2.79. As for the tangerine flavor, the values were 3.31 and 2.94, close to those determined in the present study.

\section{Microbiological assays}

The outcomes from the microbiological tests confirmed the commercial sterility of the isotonic drink, once no microorganism grew in the product.

Of particular relevance is the claim that commercial sterility of thermally processed food corresponds to the condition achieved by application of sufficient heat and/or the combination of mild thermal processing and low $\mathrm{pH}$ to render the food free from microorganisms capable of growing in the food under ambient storage conditions (Deibel \& Jantschke, 2001).

This study showed that the pasteurization and aseptic bottling were successfully applied. This is a very attractive achievement with respect to energy saving, since the product might be stored under ambient condition.

\subsection{Shelf Life Study}

Sensory analysis

Table 2 shows the average scores obtained from hedonic scale tests. Highlighted values indicate averages equivalent to or minor than 5 and percentage of acceptance minor than $60 \%$.

As expected, the average scores obtained for control samples did not differ $(p>0.05)$ along the time, showing the freezing efficiency at maintenance the beverage's acceptance.

Some variations on averages and percentages of acceptance may be explained by the use of non-trained assessors; the use of trained panel is not recommended at affective sensory tests.

Table 1. $\mathrm{pH}$ values of the isotonic beverage.

\begin{tabular}{ccc}
\hline Batch & $\begin{array}{c}\mathrm{pH} \text { of the newly } \\
\text { processed isotonic }\end{array}$ & $\begin{array}{c}\mathrm{pH} \text { after } 10 \text { days of } \\
\text { incubation at } 25^{\circ} \mathrm{C}\end{array}$ \\
\hline $\mathrm{B} 1\left(95^{\circ} \mathrm{C} / 50 \mathrm{~s}\right)$ & 3.08 & 3.00 \\
$\mathrm{~B} 2\left(90^{\circ} \mathrm{C} / 40 \mathrm{~s}\right)$ & 3.11 & 3.19 \\
$\mathrm{~B} 3\left(85^{\circ} \mathrm{C} / 30 \mathrm{~s}\right)$ & 3.03 & 0.08 \\
\hline
\end{tabular}


Valadão et al.

Table 2. Average scores obtained from the 9-point hedonic scale test for the isotonic beverage.

\begin{tabular}{|c|c|c|c|}
\hline \multirow[t]{2}{*}{ Batch } & \multirow[t]{2}{*}{ Storage time (days) } & \multicolumn{2}{|c|}{$\begin{array}{c}\text { Overall impression } \\
\text { (average } \pm \text { standard deviation / \% of acceptance }^{\star} \text { ) }\end{array}$} \\
\hline & & Control sample (stored at $-18^{\circ} \mathrm{C}$ ) & Sample stored at $25^{\circ} \mathrm{C}$ \\
\hline \multirow[t]{5}{*}{$\mathrm{B} 1\left(95^{\circ} \mathrm{C} / 50 \mathrm{~s}\right)$} & 15 & $6.4^{\mathrm{Ba}} \pm 1.6 / 85.0$ & $6.9^{\mathrm{Aa}} \pm 1.2 / 91.7$ \\
\hline & 44 & $5.9^{\mathrm{Aa}} \pm 1.9 / 71.7$ & $6.1^{\mathrm{Aab}} \pm 2.0 / 76.7$ \\
\hline & 70 & $6.3^{\mathrm{Aa}} \pm 1.6 / 83.3$ & $6.4^{\mathrm{Aab}} \pm 1.8 / 81.7$ \\
\hline & 100 & $6.5^{\mathrm{Aa}} \pm 1.7 / 83.3$ & $5.8^{\mathrm{Ab}} \pm 1.9 / 76.7$ \\
\hline & 126 & $6.6^{\mathrm{Aa}} \pm 1.3 / 90.0$ & $4.1^{\mathrm{Bc}} \pm 2.4 / 36.7$ \\
\hline \multirow[t]{6}{*}{$\mathrm{B} 2\left(90^{\circ} \mathrm{C} / 40 \mathrm{~s}\right)$} & 15 & $6.5^{\mathrm{Aa}} \pm 1.9 / 85.0$ & $6.4^{\mathrm{Aab}} \pm 2.1 / 78.3$ \\
\hline & 44 & $6.5^{\mathrm{Aa}} \pm 1.6 / 86.7$ & $6.6^{\mathrm{Aab}} \pm 1.5 / 93.3$ \\
\hline & 71 & $6.7^{\mathrm{Aa}} \pm 1.6 / 85.0$ & $7.0^{\mathrm{Aa}} \pm 1.3 / 95.0$ \\
\hline & 99 & $6.3^{\mathrm{Aa}} \pm 1.6 / 81.7$ & $6.1^{\mathrm{Aabc}} \pm 1.9 / 81.7$ \\
\hline & 128 & $6.5^{\mathrm{Aa}} \pm 1.3 / 90.0$ & $6.1^{\mathrm{Abc}} \pm 1.7 / 81.7$ \\
\hline & 160 & $6.5^{\mathrm{Aa}} \pm 1.5 / 88.3$ & $5.5^{\mathrm{Bc}} \pm 1.8 / \mathbf{5 8 . 3}$ \\
\hline \multirow[t]{7}{*}{$\mathrm{B} 3\left(85^{\circ} \mathrm{C} / 30 \mathrm{~s}\right)$} & 15 & $6.3^{\mathrm{Ba}} \pm 1.7 / 81.7$ & $6.7^{\mathrm{Aa}} \pm 1.5 / 90.0$ \\
\hline & 42 & $6.2^{\mathrm{Aa}} \pm 1.7 / 83.3$ & $6.1^{\text {Aab }} \pm 2.0 / 80.0$ \\
\hline & 71 & $6.2^{\mathrm{Aa}} \pm 1.8 / 81.7$ & $5.7^{\mathrm{Bbc}} \pm 1.9 / 70.0$ \\
\hline & 100 & $6.6^{\mathrm{Aa}} \pm 1.7 / 88.3$ & $5.8^{\mathrm{Babc}} \pm 2.0 / 71.7$ \\
\hline & 121 & $6.2^{\mathrm{Aa}} \pm 1.6 / 88.3$ & $5.5^{\mathrm{Bbc}} \pm 2.0 / 70.0$ \\
\hline & 153 & $6.5^{\mathrm{Aa}} \pm 1.3 / 88.3$ & $5.7^{\mathrm{Babc}} \pm 1.7 / 73.3$ \\
\hline & 182 & $6.4^{\mathrm{Aa}} \pm 1.4 / 86.7$ & $4.8^{\mathrm{Bc}} \pm 2.3 / 55.0$ \\
\hline
\end{tabular}

Means followed by the same upper case exponent in the same row (comparison between control and sample at $25^{\circ} \mathrm{C}$ ) and by the same lower case exponent in the same column (comparison among storage times) are not different $(\mathrm{p}>0.05)$. ${ }^{\star}$ Percentage of panelists that assigned scores greater than $5(1=$ dislike very much; $5=$ nor like/nor dislike; $9=$ like very much).

As the failure for B1 was observed at time 126 days, the best that can be said about this batch is that it survived up to 100 days. According to Guillet \& Rodrigue (2010), this situation, termed interval-censoring, is very common in shelf life testing because of the non-continuous monitoring of samples. In this situation, it is virtually impossible to know the exact failure time of each sample. Thus, the exact failure time for this sample is said to be interval-censored between 100 and 126. In this way, the estimate shelf life for B1 was 100 days. The failure time for B2 was observed after 160 days. In this way, the estimate shelf life was 128 days. Finally, B3 failured after 182 days; the estimate shelf life was 153 days.

The results of this investigation showed that the binomial time $\mathrm{x}$ temperature had a significant effect on the isotonic beverage's shelf life. The milder binomial $\left(85^{\circ} \mathrm{C} / 30 \mathrm{~s}\right)$ provided the longer shelf life. Similar result was found by Torre et al. (2003) in a study of orange juice pasteurization using different time $\mathrm{x}$ temperature binomials. Gironés-Vilaplana et al. (2016) evaluated the effect of different thermal treatments on an isotonic beverage made of fruits; the milder treatment was more effective in maintaining the drink's quality.

The regular sports drinks available in the market are mostly shelf stable and have an average shelf life of 6 months. The shelf life achieved by the product processed in this study was shorter (100 - 153 days). Nevertheless, due to its high turnover, it might be considered compatible with the consumer's demand. This difference may be explained by the addition of scotta in its formulation.

As the three batches achieved the commercial sterility, one may consider that the chemical and/or biochemical changes had a negative impact on sensory acceptance of the beverage, limiting its shelf life. However, these changes were not investigated in this study.

According to Hartel \& Heldman (1997), the magnitudes of temperature/time relationships associated with preservation processes usually result in a loss of quality attribute. These reductions in quality occur in flavor, texture, and color, as well as reductions in heat-sensitive nutrients; all these events affect the product's shelf life. In general, these types of product quality change demand that thermal process must be carefully designed to avoid over processing and unnecessary reductions in product quality. In this study, the three binomials achieved the commercial sterility. However, the milder one was more effective regarding the quality attributes preservation of the ricotta cheese whey-based isotonic beverage, providing a longer shelf life.

Petrus \& Faria (2005) formulated an isotonic beverage pasteurized at $85^{\circ} \mathrm{C} / 5 \mathrm{~s}$ with a shelf life of 180 days at ambient temperature, longer than that observed in this study. However, preservative was added to the product by those authors. Shelf life studies of ricotta cheese whey-based isotonic beverage were not found thus far.

\section{Physicochemical Analysis}

The results of $\mathrm{pH}$, titratable acidity and soluble solids at the beginning and the end of sensory shelf life are shown in Table 3. Regarding the soluble solids, there was no significant variation ( $p>0.05$ ) between samples at the beginning and the end of the product's shelf life. Similarly, there was no difference between samples stored at -18 and $25^{\circ} \mathrm{C}$. 
Table 3. Physicochemical parameters of the isotonic drink at the beginning and the end of the self life study.

\begin{tabular}{|c|c|c|c|c|c|c|}
\hline \multirow{3}{*}{ Storage time (days) } & \multirow{2}{*}{\multicolumn{2}{|c|}{$\frac{\text { Soluble solids }}{\left(^{\circ} \text { Brix }\right)}$}} & \multirow{2}{*}{\multicolumn{2}{|c|}{$\mathrm{pH}$}} & \multirow{2}{*}{\multicolumn{2}{|c|}{$\begin{array}{c}\text { Titratable acidity } \\
\text { (g citric acid/100 mL) }\end{array}$}} \\
\hline & & & & & & \\
\hline & Control & Sample & Control & Sample & Control & Sample \\
\hline \multicolumn{7}{|l|}{ Batch $1\left(95^{\circ} \mathrm{C} / 50 \mathrm{~s}\right)$} \\
\hline 15 & $6.40^{\mathrm{Aa}} \pm 0.0$ & $6.40^{\mathrm{Aa}} \pm 0.00$ & $3.10^{\mathrm{Aa}} \pm 0.01$ & $2.99^{\mathrm{Bb}} \pm 0.00$ & $0.419^{\mathrm{Ba}} \pm 0.003$ & $0.427^{\mathrm{Ab}} \pm 0.002$ \\
\hline 100 & $6.40^{\mathrm{Aa}} \pm 0.00$ & $6.40^{\mathrm{Aa}} \pm 0.00$ & $3.00^{\mathrm{Aa}} \pm 0.00$ & $3.01^{\mathrm{Aa}} \pm 0.00$ & $0.423^{\mathrm{Ba}} \pm 0.001$ & $0.464^{\mathrm{Aa}} \pm 0.005$ \\
\hline \multicolumn{7}{|l|}{ Batch $2\left(90^{\circ} \mathrm{C} / 40 \mathrm{~s}\right)$} \\
\hline 15 & $6.40^{\mathrm{Aa}} \pm 0.00$ & $6.40^{\mathrm{Aa}} \pm 0.00$ & $3.19^{\mathrm{Ba}} \pm 0.01$ & $3.21^{\mathrm{Aa}} \pm 0.01$ & $0.352^{\mathrm{Ba}} \pm 0.000$ & $0.358^{\mathrm{Ab}} \pm 0.002$ \\
\hline 128 & $6.35^{\mathrm{Aa}} \pm 0.07$ & $6.40^{\mathrm{Aa}} \pm 0.00$ & $3.10^{\mathrm{Ba}} \pm 0.01$ & $3.16^{\mathrm{Ab}} \pm 0.01$ & $0.359^{\mathrm{Ba}} \pm 0.007$ & $0.387^{\mathrm{Aa}} \pm 0.002$ \\
\hline \multicolumn{7}{|l|}{ Batch $3\left(85^{\circ} \mathrm{C} / 30 \mathrm{~s}\right)$} \\
\hline 15 & $6.40^{\mathrm{Aa}} \pm 0.00$ & $6.40^{\mathrm{Aa}} \pm 0.00$ & $2.99^{\mathrm{Aa}} \pm 0.02$ & $2.97^{\mathrm{Ab}} \pm 0.01$ & $0.391^{\mathrm{Ba}} \pm 0.001$ & $0.400^{\mathrm{Ab}} \pm 0.001$ \\
\hline 153 & $6.35^{\mathrm{Aa}} \pm 0.07$ & $6.37^{\mathrm{Aa}} \pm 0.06$ & $3.11^{\mathrm{Aa}} \pm 0.01$ & $3.16^{\mathrm{Aa}} \pm 0.03$ & $0.398^{\mathrm{Ba}} \pm 0.007$ & $0.434^{\mathrm{Aa}} \pm 0.004$ \\
\hline
\end{tabular}

Means followed by the same upper case exponent in the same row (comparison between control and sample at $25^{\circ} \mathrm{C}$ ) and by the same lower case exponent in the same column (comparison among storage times) are not different $(\mathrm{p}>0.05)$. Control: stored at $-18^{\circ} \mathrm{C}$.

With respect to $\mathrm{pH}$, there were significant ( $\mathrm{p} \leq 0.05$ ) differences between samples. However, all variations, within the same batch, were lower than 0.2 units, acceptable limit to stablish the stability of product, according to Cerf (1988). As all $\mathrm{pH}$ values were lower than 4.6 , the isotonic drink can be considered a high acid product. This characteristic favors its microbiological stability.

Regarding the acidity, significant variations were observed throughout the beverage's shelf life. The raise on titratable total acidity may have limited to the sensory acceptance of product and consequently its shelf life. According to Kilcast \& Subramaniam (2000), the total acidity is an intrinsic factor that can influence the shelf life because it affects the taste and aroma of the product.

The ratio of sugar to acid content (soluble solids content/titratable acidity) calculated for samples of Batch 1 decreased from 15 at time 0 ( 15 days of storage at $25^{\circ} \mathrm{C}$ ) to 13.8 after 100 days of storage (the end of the study). With respect to Batch 2, the ratio decreased from 17.9 (at time 0 ) to 16.5 (after 128 days). Finally, the ratio of Batch 3 decreased from 16 (t0) to 14.7 (t153). As the three batches achieved the commercial sterility, the decrease of ratio may be assigned to chemical reactions which probably occurred over ambient storage. The ratio indicates the balance between sweetness and acid in the beverage and has a great impact on product's palatability. Nevertheless, the variation observed in ratio apparently did not influence the isotonic's acceptance.

\subsection{Principal Components Analysis (PCA)}

Figure 2 depicts the PCA performed for Batches 1, 2 and 3 along with the periods of time representing the beginning (15 days) and the end of the product's shelf life. PCA was carried out with the mean values of $\mathrm{pH}$, soluble solids, titratable acidity, ratio and overall acceptance, determined at the beginning and the end of isotonic shelf life.

Figure 2 shows that principal components 1 and 2 explains $89.72 \%(51.80+37.92)$ of the total variability among isotonic samples and validates the two-dimensional representation of the components to describe sample characteristics.

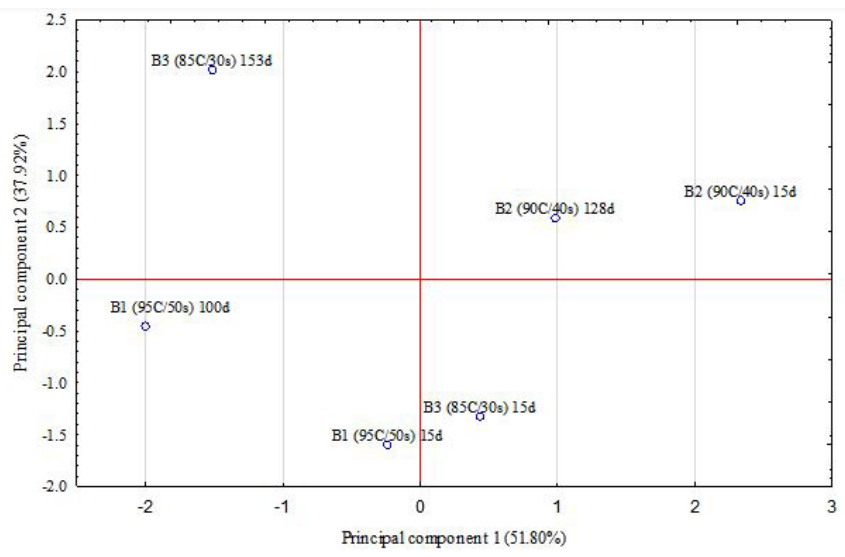

A

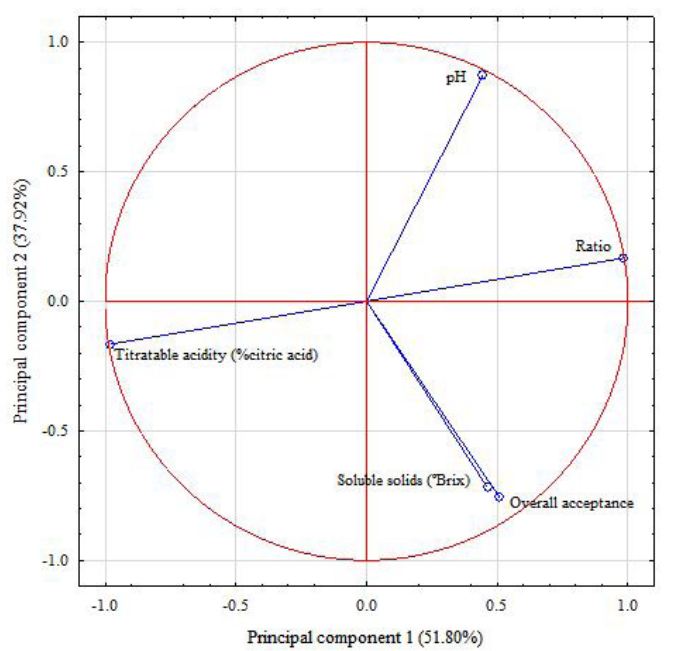

B

Figure 2. Projection of the cases (samples) (A) and the variables (B) on the plane. B1, B2 and B3 - Batches of isotonic beverage pasteurized at different conditions, at the beginning and the end of the product's shelf life. 
Figure 1A suggests that samples from B2, at the beginning $(15 \mathrm{~d})$ and the end of their shelf life $(128 \mathrm{~d})$, are similar in relation to $\mathrm{pH}$ and ratio because they are close to each other and positioned in the same quadrant. Similarly the samples of B1 and B3 are more similar at the beginning of their shelf life (15 d).

The parameters titratable acidity and ratio were the main contributors in $\mathrm{PC}$, while $\mathrm{pH}$, soluble solids and overall acceptance were the main contributors in PC2 (Figure 1B).

Longer vectors explain better the variability among samples than shorter vectors in the two-dimensional representation (Figure 1B). Vectors closer to each other indicate parameters that may have a high positive correlation. Vectors that form an angle close to $180^{\circ}$ may have a negative linear correlation. Thus, Figure 1B suggests the existence of a negative correlation between titratable acidity and ratio. The vectors that form an angle close to $90^{\circ}$, such as ratio and soluble solids, may not present significant linear correlation.

The statistical analysis of linear correlations between data confirmed that ratio and acidity presented a negative correlation between them at $5 \%$ of significance. Although the vectors for soluble solids and overall acceptance were close to each other, the positive correlation between them was not confirmed.

\section{Conclusion}

All batches of the scotta-based electrolyte replenishment beverage achieved the commercial sterility. The binomial (time $\mathrm{x}$ temperature) applied on beverage's pasteurization had no influence on the microbiological stability of the end product. The parameters of thermal treatment, by contrast, meaningfully affected the isotonic's shelf life. The milder binomial $\left(85^{\circ} \mathrm{C} / 30 \mathrm{~s}\right)$ provided the longer shelf life, compatible with an eventual demand of the consumer market. All processed batches achieved a high sensory acceptability. The principal components analysis validated the two-dimensional representation of the components to describe the sample's physicochemical characteristics. The use of scotta in the production of a commercially sterilized sports drink is a feasible alternative, adding value to a residue of the dairy industry.

\section{Acknowledgements}

The authors acknowledge the São Paulo Research Foundation for partially funding this research, and Duas Rodas, Granolab and Thech Desinfecção for the aroma, coloring, enzyme and sanitizer donation.

\section{References}

Association of Official Analytical Chemists - AOAC. (2012). Official methods of analysis (19th ed.) Arlington: AOAC.

Bottani, E., Montanari, R., Vignali, G., \& Guerra, L. (2011). A survey on packaging materials and technologies for commercial food products. International Journal of Food Engineering, 7(1), 12. http:// dx.doi.org/10.2202/1556-3758.1687.

Cerf, O. (1988). Aseptic processing in the food industry - statistical control of UHT milk. In: H. Reuter. Aseptic Packaging of Food (Chap. 6.2, p. 244-257). Hamburg: Technomic.
Corso, S., Padilha, D. M. P., Corso, A. C., \& Hugo, F. N. (2006). Evaluation on the erosive potential of powdered juices, soft drinks, sports drinks and canned teas available on the Brazilian market. Revista da Faculdade de Odontologia. Passo Fundo, 11(1), 45-50. http:// dx.doi.org/10.5335/rfo.v11i1.1444.

Deibel, K. E., Jantschke, M. (2001). Canned foods - tests for commercial sterility. In F. P. Downes \& K. Ito (Eds.), Compendium of Methods for the Microbiological Examination of Foods. (4th ed., Chap. 61, p. 577-582). Washington: American Public Health Association.

Gironés-Vilaplana, A., Huertas, J.-P., Moreno, D. A., Periago, P. M., \& García-Viguera, C. (2016). Quality and microbial safety evaluation of new isotonic beverages upon thermal treatments. Food Chemistry, 194, 455-462. http://dx.doi.org/10.1016/j.foodchem.2015.08.011. PMid:26471579.

Gironés-Vilaplana, A., Mena, P., Moreno, D. A., \& García-Viguera, C. (2014). Evaluation of sensorial, phytochemical and biological properties of new isotonic beverages enriched with lemon and berries during shelf life. Journal of the Science of Food and Agriculture, 4(6), 1090-1100. http://dx.doi.org/10.1002/jsfa.6370. PMid:24038111.

Graumlich, T. R., Marcy, J. E., \& Adams, J. P. (1986). Asseptically packaged orange juice and concentrate: a review of the influence of processing and packaging conditions on quality. Journal of Agricultural and Food Chemistry. Washington., 34(3), 402-405. http://dx.doi.org/10.1021/jf00069a004.

Guillet, M., \& Rodrigue, N. (2010). Shelf Life Testing Methodology and Data Analysis. In G. L. Robertson. Food packaging and shelf life: a practical guide (pp. 32-51). Boca Raton: CRC Press LLC.

Hartel, R. W., \& Heldman, D. R. (1997). Principles of Food Processing. New York: Springer US.

Hough, G. Sensory shelf life estimation of products. New York: CRC Press. 2010. http://dx.doi.org/10.1201/9781420092943.

Institute of Food Science and Technology - IFST. (1993). Shelf life in foods: guidelines for its determination and prediction. London: Institute of Food Science \& Technology.

Kilcast, D., \& Subramaniam, P. (2000). The stability and shelf life offood. Boca Raton: CRC Press.

Landry, W. L., Schwab, A. H. \& Lancette, G. A. (2001). Examination of Canned Food. In U.S. Food and Drug Administration (FDA). Bacteriological Analytical Manual Online (Chap. 21A). Silver Spring: FDA. Retrieved from https://www.fda.gov/Food/FoodScienceResearch/ LaboratoryMethods/ucm109398.htm>.

Maragkoudakis, P., Vendramin, V., Bovo, B., Treu, L., Corich, V., \& Giacomini, A. (2016). Potential use of scotta, the by-product of the ricotta cheese manufacturing process, for the production of fermented drinks. The Journal of Dairy Research, 83(1), 104-108. http://dx.doi.org/10.1017/S002202991500059X. PMid:26608679.

Meilgaard, M., Civille, G., \& Carr, B. (2006). Sensory Evaluation Techniques (4th ed. pp. 1-33). Boca Raton: CRC Press LLC. http:// dx.doi.org/10.1201/b16452.

Petrus, R. R., \& Faria, J. A. F. (2005). Processing and stability evaluation of isotonic drink in plastic bottle. Food Science and Technology, 25(3), 518-524. http://dx.doi.org/10.1590/S0101-20612005000300021.

Torre, J. C. M. D., Rodas, M. A. B., Badolato, G. G., \& Tadini, C. C. (2003). Sensory evaluation and consumer test of minimaly processed orange juice. Food Science and Technology, 23(2), 105-111. http:// dx.doi.org/10.1590/S0101-20612005000300021.

Valadão, N. K., Geremias-Andrade, I. M., Jory, J. C., Gallo, F. A., \& Petrus, R. R. (2016). Development of a ricotta cheese whey-based sports drink. Journal of Advances in Dairy Research, 4(3), 1-6. http:// dx.doi.org/10.4172/2329-888X.1000156. 